\title{
Work-related Conditionality and the Access to Social Benefits of National Citizens, EU and Non-EU Citizens
}

\author{
ISABEL SHUTES \\ Department of Social Policy, London School of Economics and Political Science, Houghton \\ Street, London WC2A 2AE. \\ email: i.h.shutes@/se.ac.uk
}

\begin{abstract}
This article contributes to an understanding of how conditionality applies across social security and immigration policies in restricting the access to social benefits of national citizens, EU and non-EU citizens. Specifically, the article builds on Clasen and Clegg's (2007) framework of conditionality in the context of welfare state reform by extending that conceptual framework to include migration. The framework is applied to examine how different levels of conditionality have been implemented in UK policy reforms to restrict access to rights of residence and to social benefits. It is argued that a conditionality approach moves beyond a binary of citizens and migrants in social policy analysis, contributing to an understanding of the dynamics and interactions of work-related conditions in restricting access to social benefits, with implications for inequalities that cut across national, EU and non-EU citizens in terms of the relationship of particular groups to the market.
\end{abstract}

\section{Introduction}

Debates about welfare states and migration are often framed by questions regarding the relative exclusion of migrants from the social rights of citizenship, including access to social benefits. Those debates have tended to centre on a binary distinction between citizens and migrants, with citizens constructed as a benchmark of inclusion against which the social rights of migrants are measured. Migrants may be identified as foreign nationals - as 'non-citizens' of the country to which they have migrated (for further discussion see Anderson and Blinder, 2014). However, citizens and non-citizens are not unitary groups regarding their access to social rights. As feminist scholarship has underlined, citizenship can exclude from 'within' as well as from 'without' (Lister, 2003). Policies towards both citizens and non-citizens have increasingly restricted access to the rights of citizenship or residence within a nation state, including entitlement to social benefits, on the basis of paid work/economic independence.

As regards the social rights of citizens, access to social benefits has been subject to increasing conditionality, underpinned by a market model of 
citizenship that assumes individual responsibility to participate in paid work and self-provisioning through work (Bennett and Millar, 2009; Dwyer, 2004). Within this context, work-related conditions, requiring benefits claimants to look for, prepare for and take up available work, have been extended in terms of the groups to which they apply, the type of conditions imposed, and the stringency of the conditions, including the withdrawal of benefits as a penalty for non-compliance (Dwyer and Wright, 2014).

At the same time, conditionality has also been implemented to restrict the entry, residence and access to social benefits of non-citizens. Different conditions apply to the citizenship and immigration status of particular groups, resulting in differentiated modes of inclusion and exclusion (Carmel et al., 2011; Sainsbury, 2012). While EU countries have facilitated the migration of workers from within and outside the EU, access to social benefits has been claimed to be a pull factor for 'unwanted' migration (Geddes, 2003) - despite the lack of evidence to support those claims (Corrigan, 2010; Dustmann and Frattini, 2014). In light of this, proposals for restrictions on EU citizens' access to social benefits have been put forward by member states with higher levels of EU migrants, including the UK, Germany, and the Netherlands (Ruhs, 2015). Indeed, the UK made those restrictions central to its 2015/16 negotiations on the UK's continued membership of the EU.

While inequalities between citizens and migrants in access to social benefits are evident in terms of entitlements to those benefits and, relatedly, benefits receipt (Morrissens and Sainsbury, 2005), there has been limited analysis of the ways in which conditionality restricts access. This article contributes to an understanding of how work-related conditions implemented through policy reforms restrict access to rights of residence and entitlement to social benefits across national, EU and non-EU citizens. It thus contributes more broadly to an understanding of the implications of conditionality for potentially extending inequalities among, as well as between, national, EU and non-EU citizens in terms of the relationship of particular groups to the market. It is argued that a conditionality approach moves beyond a binary of citizens and migrants by allowing for analysis of the dynamics and interactions of different types of conditions in restricting access to rights of citizenship/residence and to social benefits, while pointing to the ways in which a model of conditional rights premised on work/economic independence has exclusionary implications for all.

The article is structured as follows. The first section considers the ways in which work-related conditionality has been implemented in restricting citizens' access to social benefits, drawing on Clasen and Clegg's framework for analysing different levels of conditionality relating to welfare reform (Clasen and Clegg, 2007). Section two develops and extends that conceptual framework to include policy reform in relation to migration. The framework is then applied in sections three and four to examine empirically how those levels of conditionality have been 
implemented through policy changes in the UK, and how they interconnect in restricting EU and non-EU migrants' access to rights of residence and entitlement to social benefits. The analysis focuses on access to means-tested working-age social benefits (benefits paid to those in work and those out of work). It examines policy change in the UK over time, with a focus on recent reforms since 2010 under the Coalition/Conservative governments with respect to non-EU and EU migrant workers. Analysis of the UK policy context allows for a focus on a country where both EU and non-EU migrant workers have constituted a significant share of migration inflows. EU and non-EU nationals accounted for 48 and 52 per cent of non-British inflows in 2014, respectively. Among EU inflows, two thirds came for work-related reasons while, among non-EU inflows, a quarter came for workrelated reasons, other main reasons being for study or family (Vargas-Silva and Markaki, 2015). Within the EU, the UK also has the highest number of citizens of the member states that joined the EU since 2004 and, after Germany, the highest numbers of EU and non-EU citizens overall (Eurostat, 2015). Reference to EU migrants in the UK refers to those who have rights as EU citizens under EU $\mathrm{law}^{1}$. Reference to non-EU migrant workers in the UK refers to those who are subject to UK immigration law ${ }^{2}$. The final section addresses the implications of work-related conditionality for inequalities among, as well as between, national, EU and non-EU citizens.

\section{Work-related conditionality and access to social benefits}

With the restructuring of welfare states and the pursuit of labour market activation policies, citizens' access to social benefits has become increasingly conditional upon participation in activities which support entering or re-entering paid work (Aurich, 2011; Dwyer, 2004). While access to social benefits has for long entailed some form of conditionality, the economic crisis of 2008, it is argued, critically undermined the principle that the market could be relied upon to provide adequate incomes for all - for the subjects of labour market activation policies (Marchal et al., 2014). Income from employment - the main source of household income - fell in real terms in some OECD countries (including Ireland, Italy, Spain, Sweden, the UK, the USA) in the period 2007-2009, while income from self-employment fell across most OECD countries (Jenkins et al., 2013). While there were nominal and real increases in levels of minimum income benefits in some European countries in the period 2008-2010, the conditions attached to claiming those benefits were, notably, not relaxed and, in some countries, intensified (Marchal et al., 2014).

Clasen and Clegg (2007) define the different 'levels of conditionality' that have been implemented through policy changes across countries and within a country over time. Those levels of conditionality have acted as a 'lever' for making access to social benefits more or less restrictive (Clasen and Clegg, 2007). The first 
level of conditionality concerns 'conditions of category'. Membership of a defined category of benefits support is, as they note, socially constructed: certain groups can be included or excluded according to changing definitions of a particular category. Changes in guidance to welfare professionals on a particular category (e.g. who is eligible for unemployment benefit) can thus be a lever for restricting access to social benefits (e.g. excluding students). The second level of conditionality concerns 'conditions of circumstance', which involve eligibility criteria applied to a particular benefit, such as work-based criteria for contributory benefits and need-based criteria for non-contributory benefits, both of which can be a lever for determining and restricting access to social benefits. The third level concerns 'conditions of conduct', which apply after eligibility for a social benefit has been determined. This level of conditionality has been the focus of more recent welfare reforms, involving the obligation of benefits claimants to engage in work-related activities as a condition of their ongoing entitlement - the emphasis being on the work-related behaviour of the claimant as a condition of access.

In the UK, all three levels of conditionality are evident, and to some extent interconnect, when considering the ways in which work-related conditionality has intensified in terms of the social groups to which it applies and the stringency of the conditions. Welfare reforms have extended work-related conditions to groups claiming social benefits that would previously have been exempt from those conditions. With respect to conditions of category, lone parents with children aged five and over have now been included within the category of 'job-seekers' (the 2015 Welfare Reform and Work Bill proposes extending full work-related requirements when a child is aged 3 ). Similar restrictions apply in some other European countries (Knijn et al., 2007). Likewise, people with disabilities are now subject to a work-capability assessment to determine the category of benefits to which they are entitled (Patrick, 2011). By moving certain groups into different benefits categories, with work-based eligibility criteria attached to particular benefits, those groups have been required to comply with work-related conditions of conduct. At the same time, there has been an increase in the use of sanctions for failure to comply with conditions of conduct, such as failure to apply for a job, removing the benefits of a claimant for specific periods of time (Watts et al., 2014).

With the introduction of the Universal Credit system ${ }^{3}$, work-related conditions of circumstance and conduct are to be extended further, applying not only to benefits claimants who are not in work but to those in work. Inwork claimants will be subject to a 'conditionality threshold' regarding their weekly earnings (Dwyer and Wright, 2014). Those whose earnings fall below the threshold (equivalent to 35 hours at the national minimum wage) will be required to undergo activities to increase their earnings by increasing their hours of work and/or their wages (Universal Credit Policy Briefing No.12, 2011). Workrelated conditionality in the context of social security policy in the UK has 
thus sought to increase reliance on the market through a focus on individual work-related behaviour, requiring not simply participation in paid work but a particular number of hours of work/level of earnings. While cuts to expenditure on working-age social benefits (in work and out-of-work benefits), and a cap on total household benefits payments, have also been implemented since the 2008 crisis, which have restricted the level and coverage of benefits (Hood and Phillips, 2015), the expansion and increasing severity of conditions of conduct have likewise resulted in restriction 'from within' - the exclusion of national citizens from access to benefits.

\section{Migration and conditionality}

Migrants' access to social rights, including entitlements to social benefits, has been fundamentally shaped by the immigration policy of nation states, in addition to their welfare system (Sainsbury, 2012). Immigration and naturalisation policies determine who is granted entry to a country; the conditions of admission to a country, including access to the labour market and to social provisions; and the conditions for acquiring permanent residence or citizenship within a country (Baubock, 1994). In this section, Clasen and Clegg's framework of conditionality (2007) is extended to include policy reforms relating to migration. Clasen and Clegg's framework focuses on the levels of conditionality that apply to all with respect to social benefits claims. The following analysis takes as its starting point how these levels of conditionality apply in determining who has rights of residence/citizenship to make those claims. It thus establishes a continuum of the three levels of conditionality across immigration, citizenship and social security policies, which can be applied to make access to rights of residence and to social benefits more or less restrictive.

\section{Conditions of category}

In the context of immigration policy, conditions of category can be distinguished as the categorisation of certain groups entering a nation state as subject to immigration controls, and the categorisation of those groups according to immigration status (e.g. as workers, students, family members or asylum seekers). Those categories, like categories of social benefits support, reflect changing definitions, which can include or exclude particular groups. As regards the category of 'worker', since the late 1990s the immigration policies of OECD countries have increasingly differentiated between categories of migrant workers according to their assumed economic value, facilitating the admission of those whose labour is assessed as being of high-value, while restricting the entry of low-skilled workers (Beine et al., 2015; Ruhs, 2013; Ruhs and Anderson, 2010). Immigration policies have also aimed to facilitate admission on the basis of wealth, establishing entry routes specifically for investors (OECD, 2015). 
As regards migration from within the EU, the development of European citizenship has granted EU citizens rights to free movement across the EU, irrespective of economic status (Article 21(1), TFEU; Article 45, EU Charter of Fundamental Rights). However, work-related conditions of category apply with respect to which EU citizens have rights of residence in another member state (Directive 2004/38/EC). Extended rights of residence, beyond three months of entry, are conferred on those who are defined as workers, self-employed, jobseekers, or self-sufficient (including students), and their family members self-sufficient being defined as those who 'have sufficient resources for themselves not to become a burden on the social assistance system of the host Member State' (Article 7, 1(b), Directive 2004/38/EC). While the definition of a 'worker', which rests on EU case law, is a broad definition, based on paid employment (Case 66/85 Lawrie-Blum v Land Baden-Württemberg [1986] ECR 2121) and activities which are 'genuine and effective' (Case 53/81 Levin v Staatssecretaris van Justitie [1982] ECR 1035), in addition to excluding those engaged in unpaid work/care, how a worker is defined in practice may potentially be more or less restrictive.

\section{Conditions of circumstance}

Conditions of circumstance concern the eligibility criteria for: i) entry and temporary residence in a country (e.g. as a worker); ii) entitlement to claim social benefits; and iii) acquisition of permanent residence or citizenship. Those conditions can further restrict who has rights of residence, and under what terms and conditions.

First, the work-based criteria for the admission and temporary residence of non-EU migrant workers can be more or less restrictive. Since the 2008 economic crisis, which has had varying effects on international migration (Tilly, 2011), some European countries (e.g. Germany), in seeking to attract workers for particular occupations, have implemented measures to make the admission of high-skilled non-EU workers less restrictive while others (e.g. the Netherlands and the UK) have introduced more restrictive measures, including requiring employers to demonstrate proof of earnings for those admitted as high-skilled workers (OECD, 2015).

Second, the residence-based criteria for determining entitlement to claim social benefits on the basis of residence can be more or less restrictive. In some countries, such as Sweden, access to social benefits is granted to nonEU migrants on the basis of one year of legal residence, be it temporary or permanent (European Migration Network, 2013). In others, such as Germany and the Netherlands, non-EU migrants who have temporary residence are also, in principle, entitled to some social benefits. However, claiming those benefits can be used as grounds for non-renewal of residence status and for refusing applications for permanent residence, the eligibility criteria for permanent residence in effect restricting access to social benefits (Morris, 2001; Müller et al., 2014). In other 
countries, such as the UK, permanent residence is required of most non-EU migrants to claim social benefits, the conditions of access to permanent residence thus being a lever for restricting access to those provisions.

While EU migrants residing in another member state are entitled to claim social benefits (Article 34(2), EU Charter of Fundamental Rights), residencebased criteria may also potentially restrict access. Access to non-contributory social benefits on the basis of place of 'habitual residence' involve a broad range of criteria for determining place of habitual residence (Article 11, Regulation 987/2009/EC), which may be more or less restrictive. At the same time, the criteria for determining if an EU migrant has rights of residence in another member state under EU law, e.g. as a 'worker', may be more or less restrictive.

Third, a range of criteria may apply in determining eligibility for permanent residence or citizenship in a country (International Organization for Migration, 2009). While developments at the EU level have sought to harmonise the rights to permanent residence of non-EU citizens - requiring member states to grant permanent residence after five years of continuous legal residence (Directive 2003/109/EC) - work-related conditions of circumstance restrict who has access to those rights. Non-EU citizens must demonstrate economic independence by having stable and regular resources, sufficient to live 'without recourse to the social assistance system of the member state concerned' (Article 5, 1(a), Directive $2003 / 109 / \mathrm{EC}$ ). With respect to the UK (the focus of the following section), these provisions do not apply - indeed, the UK has taken a highly selective approach to participating in EU immigration and asylum policy (Costello and Hancox, 2014). Access to permanent residence in the UK has been marked by a tightening of both work-related conditions of category and circumstance, as the following section examines.

\section{Conditions of conduct}

Conditions of category and circumstance may indirectly require migrants to adhere to conditions of conduct - to certain types of behaviour, activity and relationships - in order to enter, reside, access social benefits, permanent residence or citizenship in a country. Migrant workers whose visa is tied to their employer are dependent on maintaining a relationship with that employer for their residence status (Anderson, 2010). Where workers are in principle entitled to change employer, they may still decide to stay with an employer and accept particular working conditions in order to meet the required duration of legal residence to apply for permanent residency (Shutes, 2012). Likewise, where economic independence is a condition of eligibility for permanent residence, migrants may be reluctant to claim social benefits even if they are, in principle, entitled to do so. Analysis of the 'civic integration' programme in the Netherlands, in which non-EU migrants are required to participate as part of the process of applying for permanent residence, highlights the ways in which self-sufficient 
behaviour is emphasised through the programme as an implicit condition for inclusion in Dutch society (Suvarierol, 2015).

While in principle EU citizens automatically have a right to permanent residence after five years of continuous legal residence in another member state (Article 16, Directive 2004/38/EC), access to permanent residence requires the EU citizen to have been able to reside over that period as a worker, self-employed or self-sufficient person (or their family member). Thus, work-related conditions of conduct - e.g. staying in work, as opposed to simply duration of residence may in effect restrict access to permanent residence.

\section{Non-EU migrants, residence and access to social benefits in the UK}

This section examines how these different levels of conditionality have been implemented through policy changes in the UK in restricting the entry, residence and access to social benefits of non-EU migrant workers. While those changes have, over time, made access to social benefits for most non-EU migrants in the UK exclusive to those granted permanent residence, the analysis highlights the ways in which recent reforms, with respect to non-EU migrant workers, have served to further tighten the conditions determining which workers have access to rights of permanent residence.

Conditions of category have increasingly restricted entry to the UK. Under the 1948 British Nationality Act, Commonwealth citizens (from the former colonies) were still granted broadly the same rights as citizens of the UK and the colonies in the post-war period of migration to the UK (Spencer, 2011). The 1971 Immigration Act introduced restrictions on the rights of entry of Commonwealth citizens, recategorising migrants from these countries as subject to immigration controls. From the late 1990s, immigration policy selectively opened up the entry of migrant workers from outside the EU on the basis of their perceived contribution to the economy (Morris, 2007). With the aim of competing for skilled non-EU migrant workers, the points-based immigration system was introduced in 2008, increasingly differentiating between categories of non-EU migrant workers on the basis of skill/income (Home Office, 2006; Spencer, 2011). Following the introduction of the system, the category for the potential entry of low-skilled workers (Tier 3) was suspended. As regards the category of 'skilled workers' permitted entry (Tier 2), the introduction of quotas in 2011 placed further limits on the entry of higher skilled workers (Home Office, 2015).

As regards entitlement to social benefits in the UK, conditions of category and circumstance have both been levers for restricting access. The national provisions of the post-war welfare state, including the introduction of National Assistance, were not exclusive to citizens of the UK. The provision of noncontributory supplementary benefit was, under the 1966 Social Security Act, 
made available to anyone in the UK, irrespective of nationality or length of residence, subject to the same eligibility criteria (Feldman, 2003). However, access to social benefits became increasingly restricted, first, through the categorisation of Commonwealth citizens as subject to immigration controls under the 1971 Immigration Act (Solomos, 2003), and second, by making 'no recourse to public funds' (no entitlement to non-contributory social benefits) a condition of entry for those subject to immigration controls (Sainsbury, 2012). At the same time, in the case of asylum seekers, who remained entitled to some means-tested social benefits, legislative changes in the 1990s increasingly restricted access by making asylum seekers ineligible for mainstream benefits, introducing a separate system of asylum support, with reduced and more restrictive types of provision (Sales, 2002).

As non-EU migrants subject to immigration controls generally have 'no recourse to public funds' (unless granted humanitarian protection), access to permanent residence or citizenship has been the basis for acquiring entitlements to social benefits in the UK. Data on grants of settlement (permanent residence) in the UK indicate an upward trend over the past 20 years, with permanent residence on the basis of work (regarding applications from non-EU workers and their dependants) becoming the most frequent category since 2008, representing 48 per cent of grants of settlement in 2012 compared with 17 per cent in 1997 (Blinder, 2014). Over that period, immigration reforms have restricted access to permanent residence by extending the required duration of legal residence in the UK to be eligible to apply. In addition, since 2010, different levels of conditionality have been implemented to further restrict access to permanent residence for those not deemed to be of 'high value' to the economy.

First, in terms of conditions of category, the range of workers that have an entitlement to apply for permanent residence has been reduced. Only those who are categorised as 'high-value' (Tier 1, including entrepreneurs) and 'skilled' (Tier 2) are entitled to apply for permanent residence after five years in the UK. Domestic workers are among those who have been excluded from access to permanent residence (Home Office, 2012). Second, regarding conditions of circumstance, the eligibility criteria for permanent residence have become more restrictive in relation to work, with the aim of 'breaking the link between work and settlement, so that only those who contribute the most economically will be able to stay long-term' (Prime Minister David Cameron, 25 March 2013). A 'genuine entrepreneur test' has been extended to assess the eligibility of entrepreneurs (under Tier 1) to apply for permanent residence (HC 1025, 26 February 2015). A minimum salary threshold will also be introduced in 2016, requiring nonEU skilled workers (under Tier 2) to have a minimum salary of $\mathfrak{E}_{35}$,000 to be eligible to apply (HC 1039, 14 March 2013). This is a higher level of pay than the salary required for temporary admission to the UK as a non-EU skilled worker $\left(\mathfrak{E}_{20}, 300\right)$, and a higher level of pay than the median gross annual earnings of all 
(full-time) workers in the UK ( $\mathfrak{2}_{27,200}$ in 2014) (Office for National Statistics, 2014).

Work-related conditions of circumstance have also been tightened for the admission of non-EU family members, requiring the applicant to have a minimum gross annual income of $\mathfrak{E} 18,6$ oo for a non-EU spouse/partner to join them, and an additional amount for children (HC 194, 13 June 2012). Based on the earnings of a sample of applicants, it was estimated that just under half would have failed to meet the new income criteria (Migration Advisory Committee, 2011). Among non-EU workers and non-EU family members, these levels of conditionality have thus restricted access to rights of residence, and entitlement to social benefits, to those who are least likely, in terms of their status in the market, to be in need of those provisions. A wider set of immigration policy changes (Immigration Act 2014; Immigration Bill 2015-16) have, more broadly, extended migration controls from within the UK.

\section{EU migrants, residence and access to social benefits in the UK}

While EU citizens, in principle, have rights to enter, reside and claim social benefits in the UK and other European countries on the basis of EU citizenship, different levels of conditionality have been implemented in the UK as a means of restriction 'from within': restricting EU migrants' access to rights of residence and social benefits.

Following EU enlargement, the UK was among those countries that did not impose transitional restrictions on the entry of A8 workers (citizens of the eight Central and Eastern European countries that joined the EU in 2004). Those who registered as 'workers' were entitled to reside, with full access to inwork benefits and child benefit, while access to out-of-work benefits required one year of continuous employment in the UK. Since EU enlargement, and particularly since the lifting of transitional restrictions on the migration of A8 nationals (in 2011) and A2 nationals (citizens of Bulgaria and Romania, which joined the EU in 2007), work-related conditions of category and circumstance have increasingly been applied in the UK to restrict EU citizens' access to social benefits.

In 2004 a 'right to reside' test was introduced, which requires EU migrants to demonstrate that they have a legal right to reside in the UK under EU law - as a worker/self-employed person or jobseeker (or their family member) - in order to be eligible to claim social benefits (SI 2006/1003; SI 2006/1026) ${ }^{4}$. The test is in addition to the 'habitual residence' requirements, which apply to all individuals who have come/returned to the UK (within the last two years), including UK citizens (SI 2014/902). With the lifting of transitional restrictions on A2 nationals in 2014, the conditions of circumstance for determining habitual residence and a 'right to reside' in social benefits claims have become increasingly restrictive. In 
addition to a minimum of three months residence (SI 2013/3196), a minimum earnings threshold has been introduced in guidance on assessing if an EU citizen is a worker/self-employed (Department for Work and Pensions, 2015; HM Revenue and Customs, 2014). This requires those out of work (who retain worker status, under EU law, if they are made involuntarily unemployed) to have been earning for the past three months at the level at which National Insurance contributions are paid ( $\mathfrak{1}_{153}$ a week in $2014-15$, equivalent to working 24 hours a week at the national minimum wage). Those who do not meet this earnings threshold are subject to an assessment as to whether their work can be considered 'genuine and effective' under EU law (Department for Work and Pensions, 2015; HM Revenue and Customs, 2014; see O'Brien, 2015, on the extent to which these measures are compatible with EU law).

Work-related conditions of circumstance have also been a lever for restricting access to social benefits for EU migrants with rights of residence as 'jobseekers' under EU law. Following legislative changes in 2014, those claiming income-based Jobseekers Allowance are subject to a 'genuine prospect of work test' after three months, losing their benefits entitlement unless they can provide 'compelling evidence' that they are continuing to seek employment and have 'a genuine chance of being engaged' (Memo DMG 2/15; SI 2013/3032, Regulation 6) 5 . Guidance on what constitutes 'compelling evidence' of finding work involves stricter workrelated conditions of conduct than those that apply to UK citizens claiming benefits as jobseekers, requiring either an offer of a job that is 'genuine and effective work' and due to start in three months (in which case benefits entitlement can be extended until the job commences), or a change of circumstances, such as relocation, that has resulted in job interviews (in which case entitlement may be extended for up to two months) (Memo DMG 2/15). With the introduction of the Universal Credit system, more restrictive conditions of category will be introduced, as a result of which 'jobseekers' will be excluded from entitlement to claim Universal Credit (SI 2015/546).

There are no data on the proportion of benefits claims of EU nationals refused on the basis of failing the right to reside test. However, there have been a number of cases in the UK and European Courts concerning EU citizens residing in the UK, including those who have been working in the UK, whose benefits claims have been refused on grounds that they do not have a 'right to reside' as a worker or jobseeker (see Widmann, 2013). The case of Saint Prix $v$ Secretary of State for Work and Pensions illustrates the dynamics and interactions of these levels of conditionality in shaping the access to social benefits of EU migrants. Jessy Saint Prix, a French citizen, had her claim for means-tested Income Support in the UK refused on the basis that she was not defined as a 'worker'. She had previously worked as a teaching assistant while studying for a teaching qualification in the UK, during which time she became pregnant. She subsequently took up agency work, working in nurseries, but stopped this work as it was too demanding in the 
latter stages of her pregnancy. Her claim for Income Support after her baby was born was refused on the basis that she did not have a 'right to reside' in the UK as she was not a 'worker' (she was considered to have voluntarily stopped working, therefore not retaining the status of worker) (2012 UKSC 49).

Conditions of category (being defined as a worker with a right to reside) and work-related conditions of circumstance (not leaving a job 'voluntarily', thereby losing the status of worker) interconnect in terms of the exclusion of Saint Prix from access to social benefits in the UK. The refusal of her claim was challenged and eventually the Court of Justice of the European Union ruled in favour of Saint Prix in 2014 regarding the interpretation of the status of worker, ruling that 'a woman who gives up work, or seeking work, because of the physical constraints of the late stages of pregnancy and the aftermath of childbirth retains the status of "worker" [...] provided she returns to work or finds another job within a reasonable period after the birth of her child' (C-507/12). While the ruling recognised the rights of EU citizens to retain their status as 'worker' during (gendered) periods of time not in paid work due to childbirth, work-related conditions of conduct are imposed in order to retain this status. Returning to work or taking up another job within a 'reasonable period' is defined in relation to national legislation on the duration of maternity leave (paragraph 42, C-507/12). This period of leave is likewise defined as a maximum of 12 months without affecting the five years of residence in a member state that is a requirement for permanent residence (paragraph 45, C-507/12). The EU migrant whose 'right to reside' depends on being a worker is thus obligated to return to work or become a jobseeker within a year of childbirth (according to UK statutory maternity leave) in order to access social benefits. As a jobseeker, if she fails to demonstrate a 'genuine prospect of work' after three months, through a job offer, she potentially loses her entitlement to social benefits. Moreover, she risks losing an entitlement to permanent residence in the long term by not re-entering work within this period.

\section{Discussion and conclusion: implications of work-related conditionality}

Different levels of conditionality apply across social security, immigration and citizenship policies in making access to rights of residence and entitlement to social benefits more or less restrictive. A conditionality approach facilitates a less static picture of rights on the basis of citizenship and immigration status, allowing for analysis of the dynamics and interactions of those different levels in restricting access to social rights across different groups. A focus on those dynamics thus moves beyond a binary of citizens and migrants in social policy analysis, pointing to the implications of a model of conditional rights premised on work/economic independence for potentially increasing inequalities among, as well as between, those groups. 
In the context of UK policy reforms, work-related conditions have restricted access to social benefits across national, EU and non-EU citizens, with the dual purpose of controlling migration and reducing welfare expenditure. Conditions of category - being defined as an EU 'worker' or a non-EU 'skilled worker' interconnect with increasingly restrictive conditions of circumstance to make not simply work but work with a minimum level of earnings a condition for access to rights of residence/permanent residence as an EU or non-EU worker. These levels of conditionality have implicitly imposed work-related conditions of conduct on the EU and non-EU citizen in order to access rights of residence as workers. The non-EU skilled worker must acquire a salary of $\mathfrak{E}_{35}, 000$ to be able to apply for permanent residence. The EU worker must provide evidence that they have a minimum level of earnings or have been in 'genuine and effective work' to be recognised as a worker with a right to reside and claim social benefits. At the same time, those claiming social benefits (both citizens and non-citizens) are subject to increasingly restrictive conditions of conduct that make not simply work but a minimum level of earnings an individual responsibility.

Work-related conditionality, in restricting access to rights of residence and entitlement to social benefits, has implications for differentiated economic and social outcomes among migrant groups, defined not simply by their status as EU or non-EU citizens but by their (gendered) labour, income and wealth. Restricted access to social benefits has generated forms of 'categorical inequality' as regards not only whether migrants (and which groups of migrants) can participate in the labour market, and under what conditions, but the extent to which they must be entirely dependent on their labour (McGovern, 2012), and thus at greater risk of poverty. Indeed, differences in levels of poverty between national, EU and non-EU citizens are found to be greatest in European countries that have implemented more restrictive conditions on access to permanent residence for non-EU citizens - with higher levels of poverty among non-EU migrants in those countries (Corrigan, 2014). At the same time, for those who are able to access rights of residence and claim social benefits, the withdrawal of benefits for failure to comply with work-related conditions has put particular groups at greater risk of poverty. Benefits claimants who have been subject to sanctions are among the most disadvantaged groups in relation to the labour market (Griggs and Evans, 2010).

Conditionality in immigration and social security policies also has implications for the distribution of the costs of meeting welfare needs. In the USA, welfare reforms that restricted the entitlement of permanent residents to federal programmes of social assistance for the first five years of permanent legal residence were associated with increasing levels of poverty among permanent residents (Broder and Blazer, 2011). Many state authorities, however, used local state-funded provision to support those made ineligible for federally-funded assistance, though cuts at the local level placed those provisions at risk (Broder 
and Blazer, 2011). In the UK, restricting access to social benefits for non-EU and EU migrants has also shifted the costs of meeting welfare needs to the local level, with non-EU migrants who have 'no recourse to public funds' as well as EU migrants denied a 'right to reside' dependent on limited local provisions and informal support (Price and Spencer, 2015). At the same time, the use of sanctions, withdrawing the benefits of claimants for failure to comply with workrelated conditions, has made those who are, in principle, entitled to national state-funded provisions dependent on sources of informal support, including food banks (Perry et al., 2014).

Public debate on welfare in the UK has been marked by myths about 'us and them': 'We are always in work, pay our taxes and get nothing from the state. They are a welfare-dependent underclass, pay nothing to the taxman, and get everything from the state' (Hills, 2014: 1). While the latter quote refers to myths in relation to citizens - to divisions between the 'hard-working' vs the 'benefitscrounging' citizen - it could equally apply to myths in relation to citizens vs migrants (e.g. see Cook et al., 2012). Levels of public expenditure on workingage social benefits, and receipt of those benefits (7.2 per cent of claimants were estimated to be non-UK citizens in 2015) (DWP, 2015), need to be framed in terms of the wider social and economic goals of welfare states in addressing the dynamics of welfare needs across population groups, during periods in and out of work over the life course (see Hills, 2014). Restricting access to social benefits, for those in low-paid work and those not in work, both through cuts and increasing conditionality, through social security and immigration policy, disproportionately affects more disadvantaged groups among citizens and noncitizens in terms of their relationship to the market. Over the long term, it potentially risks undermining the role of welfare provisions in relation to both social and economic goals.

\section{Acknowledgements}

The author gratefully acknowledges the support of the 'bEU Citizen' project, funded by the European Union's 7th Framework Programme under grant agreement 320294. I am grateful to Bridget Anderson and Sarah Walker for their collaboration on this research, and to Anne West, Fran Bennett and the anonymous referees for their helpful comments on this paper.

\section{Notes}

1 Including citizens of the European Economic Area.

2 Non-EU citizens have rights to free movement under EU law if they are the family members of EU citizens, in addition to protections under immigration and asylum policy developments. The UK has opted out of various measures on the rights of non-EU citizens (see Costello and Hancox, 2014). Reference to non-EU citizens/migrants in this article does not include non-EU migrants who are reliant on EU law, unless otherwise specified.

3 The Universal Credit system replaces various working-age benefits and tax credits with a single benefit and assessment process (Department for Work and Pensions, 2010). 
4 The 'right to reside test' applies to means-tested benefits (Income Support, incomebased Jobseeker's Allowance, income-related Employment and Support Allowance, Housing Benefit, Pension Credit, Council Tax Reduction, Universal Credit, Child Benefit and Child Tax Credit). The European Commission concluded that the right to reside test in the UK is discriminatory against EU citizens from other member states (as it does not apply to UK citizens) and referred the UK to the Court of Justice of the European Union in June 2014 (the case is ongoing).

5 EU citizens with a right to reside as a 'jobseeker' are also no longer entitled to claim Housing Benefit (SI 2014/539).

\section{References}

Anderson, B. (2010), 'Migration, Immigration Controls and the Fashioning of Precarious Workers', Work, Employment \& Society, 24: 2, 300-317.

Anderson, B. and Blinder, S. (2014), Who Counts as a Migrant? Definitions and their Consequences, Oxford: Migration Observatory, University of Oxford.

Aurich, P. (2011), 'Activating the Unemployed - Directions and Divisions in Europe', European Journal of Social Security, 13: 3, 294-317.

Baubock, R. (1994), From Aliens to Citizens: Redefining the Status of Immigrants in Europe, Aldershot: Avebury.

Beine, M., Boucher, A., Burgoon, B., et al. (2015), 'Comparing Immigration Policies: An Overview from the IMPALA Database', International Migration Review.

Bennett, F. and Millar, J. (2009), 'Social Security: Reforms and Challenges', in J. Millar (ed.), Understanding Social Security, Bristol: Policy Press.

Blinder, S. (2014), Settlement in the UK, Oxford: Migration Observatory, University of Oxford. Broder, T. and Blazer, J. (2011), Overview of Immigrant Eligibility for Federal Programs, Los Angeles/Washington D.C: National Immigration Law Center.

Carmel, E., Cerami, A. and Papadopoulos, T. (2011), Migration and Welfare in the New Europe: Social Protection and the Challenges of Integration, Bristol: Policy Press.

Clasen, J. and Clegg, D. (2007), 'Levels and Levers of Conditionality: Measuring Change within Welfare States', in J. Clasen and N. Siegel (eds.), Investigating Welfare State Change: The 'Dependent Variable Problem' in Comparative Analysis, Cheltenham: Edward Elgar.

Cook, J., Dwyer, P. and Waite, L. (2012), 'Accession 8 Migration and the Proactive and Defensive Engagement of Social Citizenship', Journal of Social Policy, 41: 2, 329-347.

Corrigan, O. (2010), 'Migrants, Welfare Systems and Social Citizenship in Ireland and Britain: Users or Abusers?', Journal of Social Policy, 39: 3, 415-437.

Corrigan, O. (2014), 'Migrant Deprivation, Conditionality of Legal Status and the Welfare State', Journal of European Social Policy, 24: 3, 223-239.

Costello, C. and Hancox, E. (2014), The UK, the Common European Asylum System and EU Immigration Law, Oxford: Migration Observatory, University of Oxford.

Department for Work and Pensions (2010), Universal Credit: Welfare that Works, London: Department for Work and Pensions.

Department for Work and Pensions (2015), Decision Makers Guide, Volume 2 Amendment 30 February 2015.

Directive 2003/109/EC concerning the status of third-country nationals who are long-term residents.

Directive 2004/38/EC on the right of citizens of the Union and their family members to move and reside freely within the territory of the Member States.

Dustmann, C. and Frattini, T. (2014), 'The Fiscal Effects of Immigration to the UK', The Economic Journal, 124 580, F593-F643.

Dwyer, P. (2004), 'Creeping Conditionality in the UK: from Welfare Rights to Conditional Entitlements?', Canadian Journal of Sociology, 29: 2, 265-287. 
Dwyer, P. and Wright, S. (2014), 'Universal Credit, Ubiquitous Conditionality and its Implications for Social Citizenship', Journal of Poverty and Social Justice, 22: 1, 27-35.

European Migration Network (2013), Migrant Access to Social Security: Policies and Practice in Sweden, Norrköping: Swedish Migration Agency.

Eurostat (2015), Migration and Migrant Population Statistics.

Feldman, D. (2003), 'Migrants, Immigrants and Welfare from the Old Poor Law to the Welfare State', Transactions of the Royal Historical Society, 13, 79-104.

Geddes, A. (2003), 'Migration and the Welfare State in Europe', The Political Quarterly, 74: 1, $150-162$.

Griggs, J. and Evans, M. (2010), A Review of Benefit Sanctions, York: Joseph Rowntree Foundation.

HC 194 (13 June 2012), Statement of Changes in Immigration Rules.

HC 1025 (26 February 2015), Statement of Changes in Immigration Rules.

HC 1039 (14 March 2013), Statement of Changes in Immigration Rules.

Hills, J. (2014), Good Times, Bad Times: the Welfare Myth of Them and Us, Bristol: Policy Press.

HM Revenue and Customs (2014), Child Benefit and Child Tax Credit Right to Reside Test: Workers and Self-employed People.

Home Office (2006), A Points-Based System: Making Migration Work for Britain, London: Home Office.

Home Office (2012), Statement of Intent: Changes to Tier 1, Tier 2 and Tier 5 of the Point Based System; Overseas Domestic Workers; and Visitors, London: Home Office.

Home Office (2015), Policy and Legislative Changes affecting Migration to the UK: Timeline, London: Home Office.

Hood, A. and Phillips, D. (2015), Benefit Spending and Reforms: The Coalition Government's Record, London: Institute for Fiscal Studies.

International Organization for Migration (2009), Laws for Legal Immigration in the $27 \mathrm{EU}$ Member States, International Migration Law No.16, Geneva: International Organization for Migration.

Jenkins, S., Brandolini, A., Micklewright, J., et al. (2013), 'The Great Recession and its Consequences for Household Incomes in 21 Countries', in S. Jenkins, A. Brandolini, J. Micklewright and B. Nolan (eds.), The Great Recession and the Distribution of Household Income, Oxford: Oxford University Press.

Knijn, T., Martin, C. and Millar, J. (2007), 'Activation as a Framework for Social Policies towards Lone Parents', Social Policy and Administration, 41: 6, 638-652.

Lister, R. (2003), Citizenship: Feminist Perspectives, Basingstoke: Palgrave Macmillan.

Marchal, S., Marx, I. and Van Mechelen, N. (2014), 'The Great Wake-Up Call? Social Citizenship and Minimum Income Provisions in Europe in Times of Crisis', Journal of Social Policy, 43: 2, 247-267.

McGovern, P. (2012), 'Inequalities in the (De-)Commodification of Labour: Immigration, the Nation State, and Labour Market Stratification', Sociology Compass, 6: 6, 485-498.

Memo DMG 2/15 Extending GPOW Assessments to Stock EEA Nationals.

Migration Advisory Committee (2011), Review of the Minimum Income Requirement for Sponsorship Under the Family Migration Route, London: Migration Advisory Committee.

Morris, L. (2001), 'Stratified Rights and the Management of Migration: National Distinctiveness in Europe', European Societies, 3, 387-411.

Morris, L. (2007), 'New Labour's Community of Rights: Welfare, Immigration and Asylum', Journal of Social Policy, 36: 1, 39-57.

Morrissens, A. and Sainsbury, D. (2005), 'Migrants' Social Rights, Ethnicity and Welfare Regimes', Journal of Social Policy, 34: 4, 637-660.

Müller, A., Mayer, M. and Bauer, N. (2014), Social Security for Third-Country Nationals in Germany, Nuremberg: Federal Office for Migration and Refugees.

O'Brien, C. (2015), 'The Pillory, the Precipice and the Slippery Slope: the Profound Effects of the UK's Legal Reform Programme Targeting EU Migrants', Journal of Social Welfare and Family Law 37: 1, 111-136. 
OECD (2015), International Migration Outlook, Paris: OECD.

Office for National Statistics (2014), Annual Survey of Hours and Earnings, 2014 Provisional Results, London: ONS.

Patrick, R. (2011), 'Disabling or Enabling: The Extension of Work-Related Conditionality to Disabled People', Social Policy and Society, 10: 3, 309-320.

Perry, J., Williams, M., Sefton, T., et al. (2014), Emergency Use Only: Understanding and Reducing the use of Food Banks in the UK, Oxford: Oxfam.

Price, J. and Spencer, S. (2015), Safeguarding Children from Destitution: Local Authority Responses to Families with 'No Recourse to Public Funds', Oxford: Centre on Migration, Policy and Society, University of Oxford.

Prime Minister David Cameron (25 March 2013), Speech on Immigration and Welfare Reform.

Regulation 987/2009/EC laying down the procedure for implementing Regulation (EC) No $883 / 2004$ on the coordination of social security systems.

Ruhs, M. and Anderson, B. (2010), Who Needs Migrant Workers? Labour Shortages, Immigration and Public Policy, Oxford: Oxford University Press.

Ruhs, M. (2013), The Price of Rights: Regulating International Labor Migration, Princeton: Princeton University Press.

Ruhs, M. (2015), Is Unrestricted Immigration Compatible with Inclusive Welfare States? The (Un)sustainability of EU Exceptionalism, Oxford: Centre on Migration, Policy and Society, University of Oxford.

Sainsbury, D. (2012), Welfare States and Immigrant Rights: The Politics of Inclusion and Exclusion, Oxford: Oxford University Press.

Sales, R. (2002), 'The Deserving and Undeserving? Refugees, Asylum Seekers and Welfare in Britain', Critical Social Policy, 22: 3, 456-478.

Shutes, I. (2012), 'The Employment of Migrant Workers in Long-Term Care: Dynamics of Choice and Control', Journal of Social Policy, 41: 1, 43-59.

SI 2006/1003 The Immigration (European Economic Area) Regulations 2006.

SI 2006/1026 The Social Security (Persons from Abroad) Amendment Regulations 2006.

SI 2013/3032 The Immigration (European Economic Area) (Amendment) (No. 2) Regulations 2013.

SI 2013/3196 The Jobseeker's Allowance (Habitual Residence) Amendment Regulations 2013.

SI 2014/539 The Housing Benefit (Habitual Residence) Amendment Regulations 2014.

SI 2014/902 The Social Security (Habitual Residence) (Amendment) Regulations 2014.

SI 2015/546 The Universal Credit (EEA Jobseekers) Amendment Regulations 2015.

Solomos, J. (2003), Race and Racism in Britain, Basingstoke: Palgrave Macmillan.

Spencer, S. (2011), The Migration Debate, Bristol: Policy Press.

Suvarierol, S. (2015), 'Creating Citizen-Workers through Civic Integration', Journal of Social Policy, 44: 4, 707-727.

Tilly, C. (2011), 'The Impact of the Economic Crisis on International Migration: a Review', Work Employment \& Society, 25: 4, 675-692.

Universal Credit Policy Briefing No.12 (2011), Conditionality under Universal Credit: the Work Search and Work Availability Requirements.

Vargas-Silva, C. and Markaki, Y. (2015), EU Migration to and from the UK, Oxford: Migration Observatory, University of Oxford.

Watts, B., Fitzpatrick, S., Bramley, G., et al. (2014), Welfare Sanctions and Conditionality in the $U K$, York: Joseph Rowntree Foundation.

Widmann, M. (2013), Welfare Benefits for Marginalised EU Migrants: Special Non-contributory Benefits in the UK, the Republic of Ireland and the Netherlands, London: The AIRE Centre. 